\title{
Siyasi Partilerin Seçim Beyannamelerinde Hedeflediği İnsan Karakterlerinin Analizi
}

\author{
DOI: $10.26466 /$ opus.640943 \\ * \\ Erdal Bay* - Recep Kahramanoğlü ${ }^{* *}$ - Bülent Döş ${ }^{* * *}$ Ümit Polat**** \\ * Prof. Dr, Gaziantep İslam Bilim ve Teknoloji Üniversitesi, İktisadi İdari ve Sosyal Bilimler \\ Fakültesi, Şahinbey / Gaziantep/ Türkiye \\ E-Posta: erdalbay@hotmail.com \\ ORCID: \\ ** Dr. Öğr. Üyesi., Gaziantep Üniversitesi, Nizip Eğitim Fakültesi, Nizip / Gaziantep/ Türkiye \\ E-Posta: recepkahramanoglu@gmail.com ORCID: 0000-0001-6670-8165 \\ *** Doç. Dr. Gaziantep Üniversitesi, Nizip Eğitim Fakültesi, Nizip / Gaziantep/ Türkiye

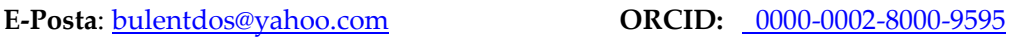 \\ **** Dr. Öğr. Üy., Niğde Ömer Halisdemir Üniversitesi, Eğitim Fakültesi, Merkez / Niğde/ Türkiye \\ E-Posta upolat@ohu.edu.tr $\quad$ ORCID: $\underline{\text { 0000-0002-0601-9074 }}$ \\ Öz
}

Bu çalışmanın amacl; TBMM'de grubu bulunan beş siyasi partinin 24 Haziran 2018 tarihinde yapılan Cumhurbaşkanı ve Milletvekili Genel Seçimi öncesinde seçim bildirgelerinde yer alan görüşlerden hareketle, hedefledikleri insan karakterini karşılaştırmalı olarak analiz etmektir. Bu bağlamda siyasi partilerin değerler, beceriler, değer kaynakları ve tutumlar boyutlarında ayn, benzer ve farkl yönleri analiz edilmiştir. Çalışmada doküman analizi yöntemi kullanılmıştır. Türkiye'de faaliyet gösteren tüm siyasi partiler içinde sadece TBBM'de grubu bulunan beş siyasi partinin seçim beyannameleri örnekleme alınmıştır. Beyannamelerden elde edilen verilerin analizinde içerik analizi yöntemi kullanılmıştır. Verilerin analizi sonucunda, kültürümüze ait "Türk, Türk Milleti" gibi ortak kültürel unsurlarm partilerin seçim beyannamelerinde farkh şekillerde yer aldığı belirlenmiştir. Siyasi partilerin seçim beyannamelerinde sosyal ve vatandaşlı, inisiyatif alma becerilerinin; iletişim, bilgi-medya becerileri, finansal okuryazarlı ve öğrenmeyi öğrenme becerilerinden daha fazla vurgulandığı görülmüş̧ür. Bireylerin sahip olması gereken beceriler boyutunda siyasi partiler arasında farkllıklar olduğu belirlenmiştir. Bireye özgü ve sosyal-toplumsal değerler en fazla yer alan değerlerdir. Değerlere en çok vurgu AK Parti en az HDP tarafindan yapılmıştır. Değerler boyutunda partiler arasında farklliklar görülmektedir. HDP demokratik değerler ve insana dair değerlere daha çok vurgu yapmaktadır. Değer kaynaklarında çeşitlilik ise en çok MHP seçim beyannamesinde yer almaktadır. MHP'nin daha çok birleştirici değer kaynakların beyan ettiğgi görülmektedir. Sonuç olarak siyasi partilerin seçim beyannameleri, 21 yy becerileri, değerler, tutumlar ve değerlerin kaynakları bağlamında bütüncül olarak değerlendirildiğinde, yetiştirilmek istenen insan tipinin net olmadığ görülmektedir.

Anahtar Kelimeler: Karakter Eğitimi, Seçim Beyannameleri, Siyasi Parti 


\title{
Analysis Of Human Characters Aimed By Political Parties In Their Election Campaign Manifestos
}

\begin{abstract}
The aim of this study is to analyze the human characters aimed by the five parties having MP groups in Turkish Grand Assembly comparatively, taking the manifestos made before the election held on 28 June 2018 into consideration. In this context, the different and similar aspects of the parties were analyzed in terms of dimensions for values, skills, sources of values, attitudes. Document analysis method was used in the study. Of the political parties operating in the political arena of Turkey, only the manifestos of the five parties having MP groups were included in the sampling. Content analysis method was used to analyze the data obtained from the manifestos. As a result of the analysis, it was determined that common cultural elements such as "Turk, Turkish Nation" belonging to our culture took place in the manifestos of the parties differently. It was found that social and citizenship skills and taking initiatives skills were emphasized more than communication, information-media skills, financial literacy, learning to learn skills in the election manifestos of the parties. It was determined that there were some differences among the parties in terms of the dimensions for the skills which should be learnt by individuals. Values were emphasized more in the manifestos of AKP and HDP that those of others. Differences among parties were seen in terms of values dimension. It was seen in the manifestos that there were some different views in terms of sources of values dimensions. HDP was found to have emphasized democratic values and humanistic values more than others. It was found that diversity in sources of values took place most in the manifestos of MHP. It was seen that MHP stated the connective sources of values most. Consequently, the type of human aimed to be trained in the manifestos of the parties is not certain when evaluated integrally in terms of 21 . Century skills, values, attitudes, sources of values.
\end{abstract}

Keywords: Character Education, Election Manifestos, Political Parties 


\section{Giriş}

Eğitim, bireyin içinde yaşadığı toplumda, yetenek, tutum, karakter gibi özelliklerini geliştirdiği süreçlerdir. Eğitimi toplumsal bir olay olarak kabul eden Durkheim, her eğitim sisteminin toplumun gereksinimlerine cevap verme yanında bireyin topluluğa uyumlu biçimde yetiştirilmesi gerektiğini savunur. Amerikalı filozof Walter Feinberg (1983) "Eğitimi Anlama" adlı kitabında eğitimin, bir toplumun kimliğini sürdürmede öncelikli bir rolünün olduğunu vurgular. Feinberg'e (1983) göre eğitim, sosyal gereksinimlere karşılık gelen sosyal yeteneklerin oluşumunu ve ikincil olarak da sosyal hayatın temelini oluşturan anlayış ve bilincin yeniden oluşumunu sağlar. Eğitimde "işlevselci" teori de, insan vücudundaki organların her birinin bir işlevinin olduğu gibi eğitimin de toplumda önemli bir işlevler gördüğünü savunur. Toplumun değerleri, normları, ortak kültürel değerler, bilgiler, beceriler ve kültürel öğeleri eğitim aracılı̆̆ıyla bireylere kazandırılır (Bay ve Döş, 2018).

Eğitimin işlevleri bağlamında bakıldığında her toplumun kendi felsefesine, yapısına uygun insan yetiştirme amacı vardır. Türk toplumunda da milletin yapısına ve beklentilerine göre yetiştirilmek istenen insanda bulunması gereken özellikler dönemsel olarak değişse de her daim olmuştur.

İslamiyet'ten önceki Türk toplumlarında yaşam biçimlerine göre "Alp" insan tipinin yetiştirilmesine önem verilmiştir (Akyüz, 2012). Alp insan tipinin temel özellikleri, onun "bilge" olduğu kadar "cesur" olmasıdır. Garipname'ye göre; "Alp" kişide sağlam yürek, pazu kuvveti, gayret, iyi bir at, özel bir giysi, iyi bir kılıç, süngü, yay ve kader birliği ettiği iyi bir arkadaş olmak üzere dokuz şey gereklidir. Oğuz Kağan Destanı'nda bu tipin en idealine rastlanmaktadır (Yardımcı,2007).

İslamiyet'ten sonra Türk toplumunda bazı değerlerin değişmesiyle yetiştirilmek istenen insan tipi değişime uğramıştır. Bu dönemde bireyin "bilge ve cesur" olmasının yanı sıra dini değerleri kazanmış bireyler olması amaçlanmıştır. Yetiştirilmek istenen insan tipinin adı "Alp-eren" olmuştur. Fuad Köprülü, İslâmiyet' in etkisinden sonraki Türk Alplerine Alp-Gazi adını vermektedir. Kişilikleri ve davranışları ile bir ülkünün peşinde olan Alpler, kişisel tutkuların üstünde topluma mal olmuş kişilerdir. Alpler, hareketli, sosyal yaşamın zorunlu bir sonucu olarak hareket unsurunun esas alındığı, güçlü erlik duygusu dediğimiz değerlerle bütünleşirler. Bu kişiler fiziksel 
olduğu kadar, ruhsal açıdan da derin bir kişiliğe sahiptir. $\mathrm{O}$, halkının öz gücünü sembolize eder. Mücadelesi uğruna geri çekilme, kaçma, yılma gibi davranışlar göstermez. Türkler, İslâmiyet'i kabul edip yerleşik hayata geçince Alplik, Battal Gazi, Danişment Gazi, Satuk Buğra Han gibi Anadolu'yu İslamlaştırmak ve Türkleştirmek için mücadele eden kahramanlarla Alp-Eren biçiminde devam etmiştir. Alplikte cesaretin yanı sıra fizyolojik bakımdan da kuvvet esastır. Çünkü Alp kişi kendi cesaret ve gücüne güvenerek mücadelelere girişir (Yardımc1,2007).

$\mathrm{Bu}$ anlayış Osmanlı'nın belirli dönemlerine kadar devam etmiştir. Osmanlı'nın son dönemlerinde bazı kesimlerce sadece "inanan ve itaat" eden bireyler yetiştirilmesi fikri ileriye sürülmüştür. Bazı yerlerde özgür ve bilimsel eğitim yerine, dinsel ve sınırlı bir eğitim verilmeye başlamış, müsbet bilimlere ilgi bireysel, istisnai ve süreksiz kalmıştır (Akyüz, 2007).

Cumhuriyet dönemi ile yetiştirilmek istenen insan tipi değişime uğramıştır. Cumhuriyet döneminde uzak hedef "çağdaş muasır medeniyetler seviyesine ulaşma" olarak belirlenmiştir. Bu uzak hedefe bağlı olarak yetiştirilmek istenen insan tipi bu hedefe ulaştıracak bireyler olarak belirlenmiştir. Cumhuriyet döneminde de dönemsel olarak yetiştirilmek istenen insan tipi politik yapıdaki ve dünyadaki değişimlerden etkilenmiştir. Birinci Cumhuriyet dönemi olarak adlandırılabilecek 1923-1938 döneminde "Millileşme"ye daha çok önem verilmiştir. "Akılcı ve milliyetçi" tanımlanacak olan Atatürk dönemi olarak da adlandırılabilen bu dönemde, eğitimin dayandığ temel unsur, Türk milli kültürü ve milli kimliği olarak belirlenmiştir. Ana gaye olarak ise, milli bir karakter çerçevesinde kendine güvenen, vatansever, ulusuna bağll, demokratik, laik, devletçi nesiller yetiştirmek olarak vurgulanmıştır (Akyüz, 2007; Binbaşığlu, 2005; Çelebi ve Asan, 2013; Meşeci, 2007). Atatürk'ün meclisin 3. başlama yılını açarken 1922'de mecliste yaptığı konuşmada hükümetin öncelikli görevinin ve en önemli ödevinin milli eğitim olduğunu vurgulaması ve yetiştirilmek istenen çoçuklarda/ bireylerde ulusuna ve vatanına bağlı olma değerleri belirtilmiştir (Çelebi ve Asan, 2013). Bu çerçeve cumhuriyet dönemi eğitim felsefesinin ana omurgasının toplumcu olduğu ve Ziya Gölalp'in savunduğu sosyolojizm kökenli E. Durkheim anlayışında bir eğitim sistemi olduğu ifade edilebilir (Hesapçıŏlu, 2009).

1947 yılında Amerika ile yapılan eğitim işbirliği anlaşması ile Türk eğitimciler Amerika'ya lisansüstü eğitim almaya gitmişlerdir. 1950'li yıllarda 
Amerika doktoralı Türk eğitimcilerin Türkiye dönmesiyle birlikte Amerikan pragmatizmine doğru bir paradigma kayması olsa da, aslında Gökalp'in düşüncesi yani toplum kökenli felsefe varlığını devam ettirmiştir (Hesapçıŏlu, 2009). Toplum kökenli felsefeden birey merkezli felsefeye geçiş 2000'li yıllarda gerçekleşmiştir. 2004-2005 yılı itibariyle uygulamaya konan yeni iklöğretim programının temeli, birey merkezli bir anlayışı oluşturmaktadır. Pragmatizmin izleri daha belirgin olarak bu programlarda görülmektedir. Bu bağlamda farklı dönemlerde baskın olarak ortaya çıkan eğitim felsefeleri insan yetiştirme anlayışında da farklılık ortaya koymaktadır. Dolayısıyla yapılan bu çalışmada, günümüzde yetiştirilmek istenen insanda bulunması gereken özelliklerin ne olduğu sorusu, siyasi parti beyanlarına göre cevaplandırılmaya çalışılmıştır. Bu konu eğitimin siyasal temelleri ve politik işlevleri ile doğrudan ilişkilidir.

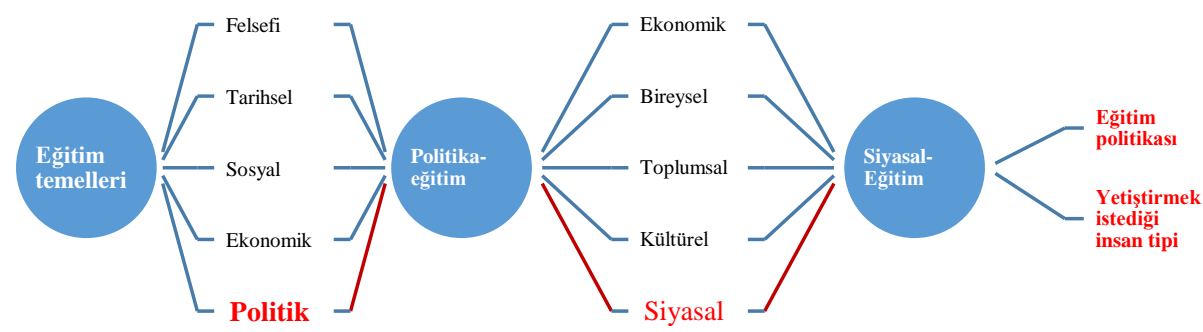

Şekil 1. Eğitim politika ilişkisi

Şekil 1'de görüleceği gibi, eğitimin tarihsel, sosyal, felsefi, ekonomik temelleri yanında politik temelleri de vardır. Politik temeller bağlamında eğitim ile politika arasında çok yönlü ilişkiler olduğu söylenebilir. Eğitimin temelleri arasında yer alan politik temeller, eğitim üzerinde, ekonomik, siyasal, sosyal, bireysel, toplumsal ve kültürel alanlarda etkilere sahiptir. Bu etkiler içerisinde politikanın eğitim üzerindeki siyasal etkisi ilk olarak amaçların, önceliklerin neler olması gerektiği, başka deyişle eğitim politikalarının nasıl olması gerektiği boyutundadır. İkinci boyut ise nasıl bir insan yetiştirilmesi gerektiği boyutundadır. 
Kelly (2009) eğitimi, toplumun gençlerini yetişkin hayatına hazırladığı siyasal bir aktivite olduğunu belirtmiştir. Siyasi bağlamın eğitim sistemlerinin ana öğesi olduğunu vurgular. Bu bağlamda aynı görüşü paylaşan insan grupları, toplumun nasıl gelişeceğine dair ideolojik inançlarına dayalı kendi politikalarını biçimlendirmek için bir araya gelirler. Bu gruplar siyasi parti olarak resmileştirilirler. İktidara geldiklerinde de bu politikalarını uygularlar (Barlett ve Burton, 2014).

Her siyasi partinin yetiştirmek istediği insan tipi aynı olmamaktadır. Özellikle toplumsal sistemdeki politik yapıdaki farklılıklar bu sorunun cevabının verilmesini güçleştirmektedir. Bu nedenle hangi siyasi parti egemen ise kendi politik anlayışın bireylere aktarmak istemektedir. Fred İnglish (1985) eğitim alanine, entelektüel sivil savaş ve kültürel otorite savaş1 için gayretli bir savaş alanı olarak tanımlanmaktadır. Young'a (1999) göre de program sosyal olarak inşa edilir ve kuvvet dağılımı, güç odakları ve program arasında güçlü bir ilişki vardır.

Siyasi partiler seçim bildirgeleri aracılığıyla yapmak istediklerini paylaşmaktadırlar. Seçim beyannameleri toplum ile devlet arasındaki bağı kuran siyasi partilerin iktidara geldikleri takdirde yürütecekleri politikaları kamuoyuna açıkladıkları bildiri metinleridir. Seçim vaatleri, parti programlarının yanı sıra seçim beyannameleri de siyasi partilerin görüşlerini açılamaktadır. Seçim beyannamelerinde ekonomik, sosyal alanların yanında siyasi partilerin yetiştirmek istediği insanda bulunması gereken özellikler de görülebilmektedir.

Alanyazın incelendiğinde partilerin hedefledikleri insan profili ile ilgili doğrudan hiçbir çalışma yapılmadığı, diğer çalışmaların siyasi partilerin eğitim söylemleri, politikaları ile ilgili olduğu görülmüştür (Gürsoy ve Balc1 Karaboğa, 2015; Toprakçı ve Akçay Güngör, 2014; Tok, 2012; Bulut ve Güven, 2010; Aydın, 1997). Türk Eğitim Derneği (TEDMEM) (2018) tarafından "siyasi partilerin 2018 seçim bildirgeleri eğitim alanındaki politika ve vaatlerin karşılaştırılması" başlıklı rapor yayınlanmıştır. Bu raporda da eğitim alanıyla ilgili 23 tema altında siyasi partilerin seçim beyannameleri analiz edilmiştir. İlgili çalışmada da siyasi partilerin insan profili tema olarak ele alınarak incelenmemiştir.

Bu çalışmada ülkemizde "başkanlık" sistemine geçildiği ve eğitimde 2023 vizyon belgesinin açıklandığı, 21. yy becerilerinin ön plana çıktığı bu günlerde yetiştirmek istediğimiz insan tipinin ne olduğunu başka bir deyişle 
yetiştirmek istediğimiz insanda bulunması gereken özelliklerin neler olması gerektiğine ilişkin soruya cevap aranmıştır. Bunun için de TBMM'de grubu bulunan beş (5) siyasi partinin seçim beyannameleri analiz edilmiştir.

\section{Araştırma Soruları}

Çalışmanın ana amacı TBMM'de grubu bulunan beş siyasi partinin 24 Haziran 2018 tarihinde yapılan Cumhurbaşkanı ve Milletvekili Genel Seçimi öncesinde seçim bildirgelerinde yer alan görüşlerden hareketle hedefledikleri insan karakterini karşılaştırmalı olarak analiz etmektir. Bu bağlamda aşağıdaki sorulara cevaplar aranmıştır?

1. Siyasi partilerin seçim beyannameleri kaç kelimeden oluşmaktadır ve en çok vurgu hangi kelime/kavramlardır?

2. Siyasi partilerin seçim beyannamelerinde yer alan 21. yy becerileri nelerdir?

3. Siyasi partilerin seçim beyannamelerinde yer alan değerler nelerdir?

4. Siyasi partilerin seçim beyannamelerinde yer alan değerlerin kaynakları nelerdir?

5. Siyasi partilerin seçim beyannamelerinde yer alan tutumlar nelerdir?

\section{Araștırmanın Önemi}

Bu çalışma, siyasi partilerin hedefledikleri insan karakterine ilişkin ilk sayılabilecek bir çalışma olması nedeniyle önemli sayılabilir. Bu çalışma politika oluşturucu ve uygulayıcılara seçim politikalarını değerlendirmelerine olanak sağlayabilecek geribildirim verebilecektir. Nihai olarak siyasi partiler topluma yarar sağlamak için politikalar geliştirmektedirler. Ayrıca elde edilecek veriler, Türkiye'yi yönetme iddiası olan siyasi partilerin yetiştirilmek istenen insan tipinin nasıl olduğuna ilişkin akademik bir tartş̧ma zeminin oluşmasına katkı sağlayacağı beklenmektedir.

\section{Yöntem}

Bu çalışmada, denek ve katılımcı tepkiselliği sorununa neden olmayan, alan yazını analiz ederek araştırma sorularını detaylı açıklayabilme olanağı veren 
doküman incelemesi yöntemi kullanılmıştır. Bu yöntem, geçmişten günümüze her türlü yazılı belge, fotoğraf ve film gibi dokümanların incelenmesinde kullanılmaktadır (Yıldırım ve Şimşek, 2016).

Doküman analizi yöntemi,

i) Dokümanlara ulaşma,

ii) Orijinalliği kontrol etme

iii) Dokümanları anlama

iv) Veriyi analiz etme ve

v) Verinin kullanımı aşamalarından oluşur.

Çalışma kapsamında dokümanlara ulaşma aşamasında Türkiye'de faaliyet gösteren tüm siyasi partiler içinden sadece TBMM'de grubu bulunan beş siyasi partinin seçim beyannameleri örnekleme alınmıştır. Seçim beyannameleri partilerin politikalarını yansıtan en resmi dokümanlar olduğu için öncelikli olarak tercih edilmiştir. Bu bağlamda araştırma sadece seçim beyannameleri ile sınırlıdır. Seçim beyannamesi dışındaki söylemler çalışmaya dahil edilmemiştir.

Partilerin resmi web sayfalarından "seçim beyannameleri"ne ulaşılmıştır. Bu süreçte siyasi partilere seçim beyannamelerinin çalışma için kullanılmak istendiğine dair mailler gönderilmiştir. Orijinalliğin kontrolünde, belgeler incelenirken ulaşılan web sayfasındaki URL adresleri kontrol edilerek ilgili birimin resmi web sayfası olduğu onaylanmıştır. Seçim beyannameleri partilerin kendi resmi web sayfalarından alındığ 1 için orijinallik kontrolü için ek işlem yapılmamıştır.

Dokümanları anlama aşamasında, araştırmacılar tarafından siyasi partilerin seçim beyannamelerinin araştırma amacına uygun içeriklere sahip oldukları bulunmuştur.

Verilerin analizi basamağında, seçim beyannamelerinin başlı başına araştırmanın veri seti olduğuna karar verilmiştir. Veri analizinde ilk olarak örneklem seçme işlemi yapılmıştır. Siyasi partilerin hedefledikleri insan karakterine yönelik verileri belirlemek için seçim beyannamelerinin tüm bölümlerinin $\mathrm{mi}$, yoksa sadece eğitim politikalarına yönelik bölümlerinin $\mathrm{mi}$ incelenmesi gerektiği tartışılmıştır. Amaç doğrultusunda yapilan ön incelemede insan karakterine ilişkin öğelerin sosyal, ekonomik vb. her boyutta bulunabileceğinden hareketle seçim beyannamelerinin tüm içeriği analiz kapsamına alınmıştır. 
Araştırmada analiz birimi olarak önce kodlar belirlenmiştir. Kodlar temalara, temalar da kategorilere dönüştürülmüştür. Seçim beyannameleri metin olarak okunmuş daha sonra belirlenen kodlarla ilgili cümlelerden alıntı yapılmıştır.Tablo 1'de veri analizine örnek gösterilmiştir.

Tablo 1. Veri analizine örnek

\begin{tabular}{ll}
\hline Orijinal metin & Kategori/tema/kod \\
\hline $\begin{array}{l}\text { Öğretim programları düşünme ve öğrenmeyi öğretmeye odaklı, bilg- } \\
\text { iye erişen, bilgiyi analiz edip işleyerek değer süreçlerine aktarma }\end{array}$ & $\begin{array}{l}\text { Ekiple çalışma (beceri) } \\
\text { Bilgiyi analiz etme-medya } \\
\text { yetenekleri geliştirilmiş, ekip çalışmasına uyumlu bireylerin } \\
\text { okuryazarlığı (beceri) }\end{array}$ \\
$\begin{array}{l}\text { yetiştirilmesi hedeflerine dönük olarak ele alınmalıdır. Eğitimin her } \\
\text { kademesinde müfredatın millî ve çağın gereklerine uygun bir şekilde } \\
\text { planlanması ve uygulanması esas olmalıdır. }\end{array}$ & \\
\hline $\begin{array}{l}\text { Önümüzdeki dönemde gelirini daha adil paylaşan ve nesiller } \\
\text { arasıhakkaniyeti sağlamıs; çalışma istek, yetenek ve becerisine sahip; }\end{array}$ & Adalet (değer) \\
$\begin{array}{l}\text { Çalşkanlık } \\
\text { hëkesin yönetime katkıda bulunduğu; demokratik standartları }\end{array}$ & Demokrasi \\
\hline
\end{tabular}

Her bir araştırmacı tarafından ayrı olarak belirlenen kodlar, tema ve kategoriler altında toplanmıştır. Bir araya gelinerek kodlar ve temalar üzerinde düzeltme ve değişiklikler tekrar yapılmıştır. Bir sonraki aşamada belirlenen kodlar siyasi parti beyannamelerinde tekrar taranmıştır. Bu şekilde geçerlilik ve güvenirlik artırılmaya çalışılmıştır. Veri analizinde beceri, değer, değer kaynakları ve tutum başlıkları kategoriler olarak alınmıştır.

Veri analizinde değer kategorisi altında belirlenen değerlerin, tema olarak sinıflandırılmasında ise Acat ve Aslan (2012) tarafından belirlenen değer sınıflandırılması kullanılmıştır. Sınıflandırma muhafazakâr-geleneksel, ulusal, bireye özgü-kişisel, sosyal-toplumsal ve bilimsel-yenilikçi değerler olarak isimlendirilmiştir.

Çalışmada veriler doğru biçimde ve derinlemesine toplanmıştır. Güvenirlik ve geçerliliği artırmak için seçim beyannamelerinde elde edilen sonuçlar siyasi partilere mail olarak gönderilmiştir. Araştırmacıların her birinin ayrı ayrı kodlama yapması ve daha sonra görüş birliği varması güvenirliğe yönelik olarak yapılmıştır.

Araştırmanın sadece seçim beyannameleri ve mecliste grubu olan partilerle ilgili yapılmış olması sınırlılıktır. Yine bulgular, söylem analizi yapılmaması, eğitim sistemlerini etkileyen politik ideolojilerle (örnek neo-liberalizm...) ilişkilendirilmemesi de bir diğer sınırlılıktır. 


\section{Bulgular ve Tartışma}

Bu bölümde araştırmanın bulgularına ve tartışmalara yer verilmiştir.

\section{Araştırmanın Birinci Sorusu Ile Ilgili Bulgular}

Araştırmada ilk olarak siyasi partilerin seçim beyannamelerinin kaç kelimeden oluştuğu analiz edilmiştir.

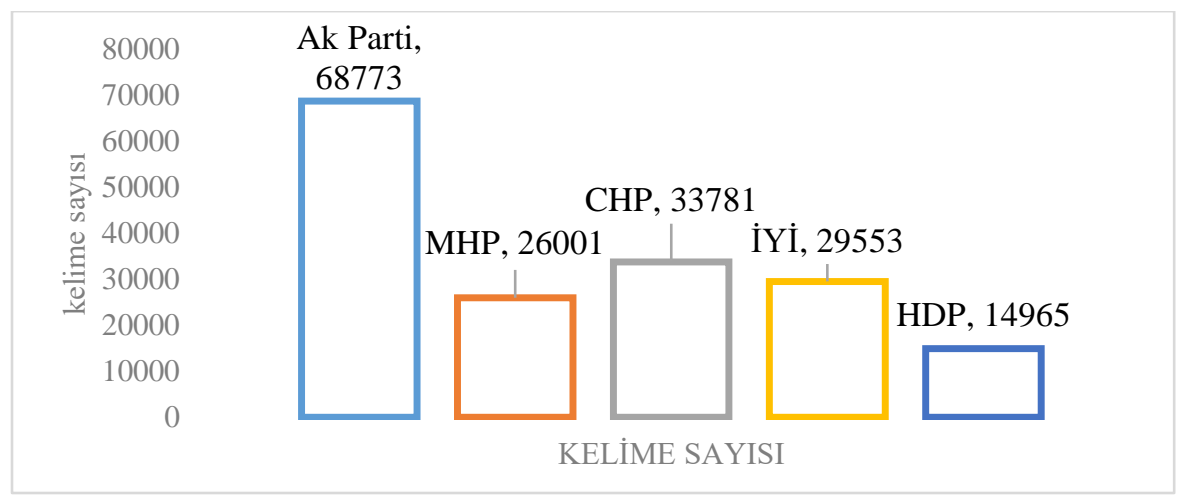

Grafik 1. Siyasi parilerin seçim beyannamelerinde kelime sayısı

Grafik 1'de görüldüğü gibi en çok kelime sayısı AK Parti, en az ise HDP seçim beyannmesinde yer almaktadır. Seçim beyannameleri seçim öncesinde partilerin vaatlerde bulundukları politik metinlerdir. Araştırmada kelime sayısının en çok AK Parti, en az HDP seçim beyannamelerinde yer aldığı sonucuna ulaşılmıştır. Kelime sayıları açısından siyasi partiler AK Parti- CHP- MHP- IYİ Parti ve HDP olarak sıralama göstermektedir. Yıldırmaz (2018) tarafından yapılan çalışmada da kelime sayılarında farklılıklar olsa da aynı sıralama olduğu görülmüştür. Freud'un da dediği gibi: "Söz" ve "sihir" başlangıçta aynı şeylerdir. Kelimelerin sihirli güçleri vardır" (Yıldırmaz, 2018). Seçim beyannamelerinde kelimeler seçmenleri etkilemede önemli rol oynayabilirler. Niteliksel içerik önemli olmakla beraber seçmeni ilgilendiren görüşleri detaylı bir şekilde seçim beyannamesinde açıllamak önemlidir.

Araştırma kapsamında siyasi partilerin seçim beyannamelerinde bazı kavramların nasıl yer aldığı da araştırılmıştır. Siyasi partilerin seçim 
beyannamelerinde odak kavramlar olarak Türk, Atatürk, vatan, Türk Milleti, İslam ve Kur'an kavramları alınmıştır. Bulgular Tablo 2' de verilmiştir.

Tablo 2. Siyasi partilerin seçim beyannamelerinde geçen bazı odak kavramlara ait sayısal veriler

\begin{tabular}{llllll}
\hline & AK PARTI & MHP & CHP & IYI & HDP \\
\hline Türk & 78 & 138 & 16 & 51 & 1 \\
\hline Atatürk & - & 3 & 8 & 3 & - \\
\hline Vatan & 1 & 6 & - & - & - \\
\hline Türk Milleti & - & 55 & 1 & - & - \\
\hline İslam & 28 & 19 & - & 1 & - \\
\hline Kur'an & 3 & - & - & - & - \\
\hline
\end{tabular}

Beyannamelerde "Türk" kavramina vurgu en fazla MHP tarafindan yapılırken, en az HDP tarafından yapılmıştır. "Atatürk" kavramı AK Parti ve HDP'de hiç yer almazken, en fazla CHP'de, daha sonra ise MHP ve İẎ Partide yer almaktadır. "Vatan" kavramı en çok MHP seçim beyannamesinde vurgulanırken, CHP, İYİ Parti ve HDP'de hiç değinilmemiştir. "Türk Milleti" kavramına sadece MHP ve CHP vurgu yapmıştır. En çok ise MHP beyannamesinde vurgulanmıştır. "İslam" kavramı en çok AK Parti tarafından ifade edilirken, ikinci sırada ise MHP beyannamesinde vurgulanmıştır. CHP ve HDP bu kavrama vurgu yapmamıştır. "Kur'an" kavram olarak sadece AK Parti seçim beyannamesinde yer almaktadır.

Siyasi partilerin seçim beyannamelerinde kültürümüzle ilgili ortak kavramlarında nasıl geçtiği analiz edildiğinde, partiler arasında farklılıklar olduğu belirlenmiştir. "İslam" AK Parti ve MHP seçim beyannamesinde, "Kuran" sadece AK Parti beyannamesinde yer almaktadır. "Türk Milleti ve vatan" kavramin kullanan tek parti MHP'dir. Türkiye Cumhuriyeti'nin kurucusu "Atatürk", diğerlerine oranla en çok CHP beyannamesinde yer almaktadır. Bu çalışmada sadece parti beyannamelerinin esas alınmış olması, parti temsilcilerinin söylemlerinin analiz edilmemiş olması bir sınırlılık olarak kabul edilmiştir. Belki de bu tür söylemlerde bu kavramlar geçiyordur. Fakat parti seçim beyannamelerinde söylenenler kadar, söylenmeyenlerde ve söylen/e/meme sebepleri de önemlidir. Bir ülkede siyaset yapan partilerin ülkenin ortak değerlerini benimsemesi ve yansıtması, uygulayacă̆ı politikalarm etkililiğini artırabilecektir. 


\section{İkinci Araştırma Sorusu Ile Bulgular}

Araştırma kapsamında partilerin seçim beyannamelerinde yer alan "beceriler"in neler olduğu araştırılmıştır. Elde edilen genel sonuçlar aşağıdaki şekil 2'de ve tablo 3'te gösterilmiştir.

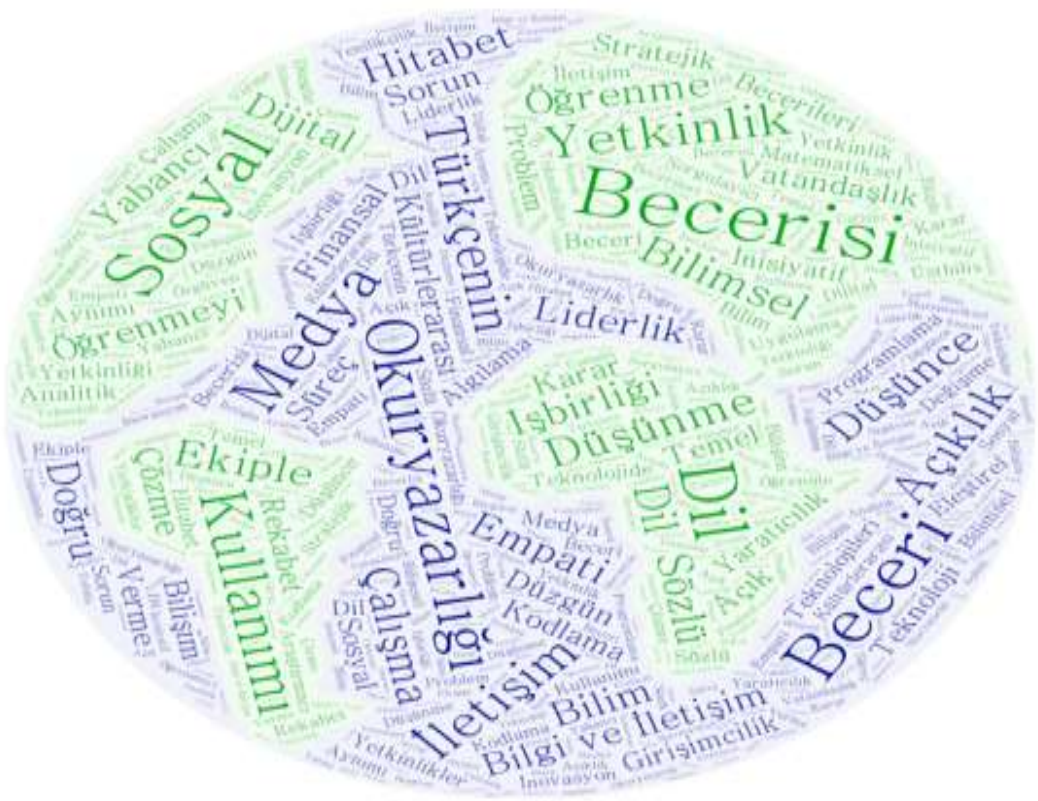

Şekil 2. Siyasi partilerin seçim beyannamelerinde geçen beceriler

21. yy becerileri arasında yer alan "sosyal ve vatandaşlık, iletişim, inisiyatif alma, matematiksel ve bilim teknolojide yetkinlik, öğrenmeyi öğrenme" becerileri tüm siyasi partilerin seçim beyannamelerinde farklı düzeylerde yer almaktadır. Becerilere genel olarak bakıldığında en çok tekrarlanan beceriler inisiyatif alma yetkinliği ile sosyal ve vatandaşlık becerisi ile yenilikçilik becerileridir. Bilgi okuryazarlığı, BİT okuryazarlığı, bilimsel süreç uygulama, kültürlerarası beceri gibi özelliklerin siyasi partilerin seçim beyannamelerinde yer almadığı görülmektedir. 
Tablo 3. Siyasi partilerin seçim beyannamelerinde yer alan 21 yy. Becerileri

\begin{tabular}{|c|c|c|c|c|c|}
\hline 21. YY BECERİLER & AK PARTİ & MHP & CHP & İYİ & HDP \\
\hline İnisiyatif alma yetkinliği & 95 & 27 & 29 & 36 & 1 \\
\hline Rekabet & 72 & 26 & 28 & 22 & 1 \\
\hline Girişimcilik & 23 & 1 & 1 & 14 & \\
\hline Sosyal ve vatandaşlık becerisi & 100 & 23 & 29 & 28 & 2 \\
\hline İşbirliği & 94 & 22 & 26 & 27 & 2 \\
\hline Liderlik & 5 & & 2 & & \\
\hline Empati & & 1 & & & \\
\hline İletişime açıklık & 1 & & & & \\
\hline Sosyal beceri & & & 1 & 1 & \\
\hline \multicolumn{6}{|l|}{ Kültürlerarası beceri } \\
\hline Yenilikçilik & 30 & 7 & 1 & 9 & \\
\hline $\begin{array}{l}\text { Matematiksel Yetkinlik Ve } \\
\text { Bilim/Teknolojide Temel Yetkinlikler }\end{array}$ & 5 & 10 & 5 & 4 & 2 \\
\hline Problem/sorun çözme becerisi & 3 & 3 & & 1 & \\
\hline İnovasyon & & 3 & 2 & 1 & \\
\hline Düşünme becerisi & 2 & 2 & & 1 & \\
\hline Yaratıcilık & & & 3 & & 1 \\
\hline Karar verme & & 1 & & 1 & 1 \\
\hline Algilama becerisi & & 1 & & & \\
\hline \multicolumn{6}{|l|}{ Bilimsel süreç uygulama } \\
\hline Öğrenmeyi öğrenme becerisi & 4 & 6 & 6 & 4 & 1 \\
\hline Sorgulayıcı olma & 1 & 1 & 3 & 3 & 1 \\
\hline Araştırmacı & 1 & 2 & 1 & & \\
\hline Bilimsel düşünce & & 2 & & 1 & \\
\hline Öğrenmeyi öğrenme & 2 & 1 & & & \\
\hline Analitik düşünme & & & 1 & & \\
\hline Eleştirel düşünce & & & 1 & & \\
\hline \multicolumn{6}{|l|}{ Üst biliş } \\
\hline Bilgi, medya ve teknoloji becerileri (Dijital) & 5 & & 2 & 7 & \\
\hline Kodlama & 5 & & 1 & 3 & \\
\hline Programlama & & & & 3 & \\
\hline Medya okuryazarlığı & & & 1 & & \\
\hline Bilişim okuryazarlığı & & & & 1 & \\
\hline \multicolumn{6}{|l|}{ Bilgi okuryazarlığı } \\
\hline \multicolumn{6}{|l|}{ Bilgi ve iletişim teknolojileri (BİT) okuryazarlığ1 } \\
\hline İletişim (Dil) becerisi & 5 & 1 & 3 & 3 & 1 \\
\hline Yabancı dil becerisi & 2 & & 2 & 2 & \\
\hline Türkçenin doğru ve düzgün kullanımı & 2 & 1 & & & \\
\hline Hitabet & & & & 1 & \\
\hline Sözlü iletişim & 1 & & & & \\
\hline Stratejik iletişim & & & 1 & & \\
\hline Değişime açık olma & 6 & & 1 & 3 & \\
\hline Özgüven & 4 & & 1 & 1 & \\
\hline Finansal okuryazarlık & 1 & & & 2 & \\
\hline
\end{tabular}


İçinde yaşadığımız çağda inisiyatif alma becerisi başka bir deyişle rekabetçilik, girişimcilik becerileri çok önemlidir. Bu durum siyasi partilerin seçim beyannamelerinde de görülmektedir. HDP dışında diğer partilerin bu becerileri önemsedikleri görülmektedir. "İnisiyatif alma" becerisine en çok vurgu AK Parti tarafından, ikinci en çok vurgu İYİ Parti tarafından ve en az vurgu ise HDP tarafından yapılmıştır. İnisiyatif alma becerisi kapsamında en çok vurgulanan beceriler rekabet ve girişimcilik alt boyutlarıdır. "Rekabet" alt boyutuna vurguyu en çok AK Parti yaparken, bütün partilerin seçim beyannamelerinde geçtiği görülmektedir. Girişimcilik becerisine yine en çok vurgu AK Parti tarafından yapılırken, bu beceriye HDP tarafından yer verilmediği ortaya çıkmıştır.

"Sosyal ve vatandaşlık becerisi"ne en çok vurgu AK Parti tarafından, ikinci en çok vurgu CHP tarafından ve en az vurgu ise HDP tarafından yapılmıştır. Sosyal ve vatandaşlık becerisi alt boyutunda en çok vurgulanan beceri "işbirliği" olmuştur. Sosyal ve vatandaşlık becerisinin alt boyutları arasında yer alan "empati, iletişime açıklık, sosyal beceri, liderlik" gibi becerilerin çok az yer aldığı görülmektedir. Sosyal ve vatandaşlık becerisinin alt boyutlarından olan "işbirliğii" en çok AK Parti tarafından, en az HDP tarafından ifade edilmiştir. "Empati" sadece MHP tarafından belirtilmiştir. 21. yy becerileri arasında yer alan "Sosyal ve vatandaşlık" becerilerine siyasi partiler tarafından yeterince yer verilmediği söylenebilir.

"Yenilikçilik" becerisine en çok vurgu AK Parti tarafından, ikinci en çok vurgu IYII parti tarafından ve en az vurgu ise CHP tarafından yapılmıştır, HDP hiç vurgu yapmamıştır.

"Finansal okuryazarlık" becerisinin, en az vurgu yapılan beceri olduğu görülmektedir. Bu beceriye seçim beyannamelerinde sadece AK Parti ve IYYI parti vurgu yapmış, diğer partiler hiç vurgu yapmamıştır.

Türk toplumu olarak modern dünyada en çok gereksinim duyduğumuz becerilerden olan "iletişim" becerisi de siyasi partilerin seçim beyannamesinde en az yer alan beceriler arasindadır.

Problem çözme, düşünme, yaratıcllık, karar verme, algılama gibi "matematiksel ve bilimsel yetkinlik" becerileri açısından siyasi partilerin bu beceriye yeterince vurgu yapılmadığı ortaya çıkmıştır.

Siyasi partilerin seçim beyannamelerinde sorgulayıcı, araştırmacı, analitik, eleştirel düşünce gibi "öğrenmeyi öğrenme" becerisi ile değişime açık olma, özgüven gibi becerilerin de yeterince yer almadığı görülmektedir. 


\section{Araştırmanın Üçüncü Sorusu Ile Ilgili Bulgular}

Araştırmada siyasi partilerin seçim beyannamelerinde yer alan "değer"lerin neler olduğu incelenmek istenmiştir. Beş siyasi partinin beyannamelerinde yer alan değerler bütüncül olarak Şekil 3'te gösterilmiştir.

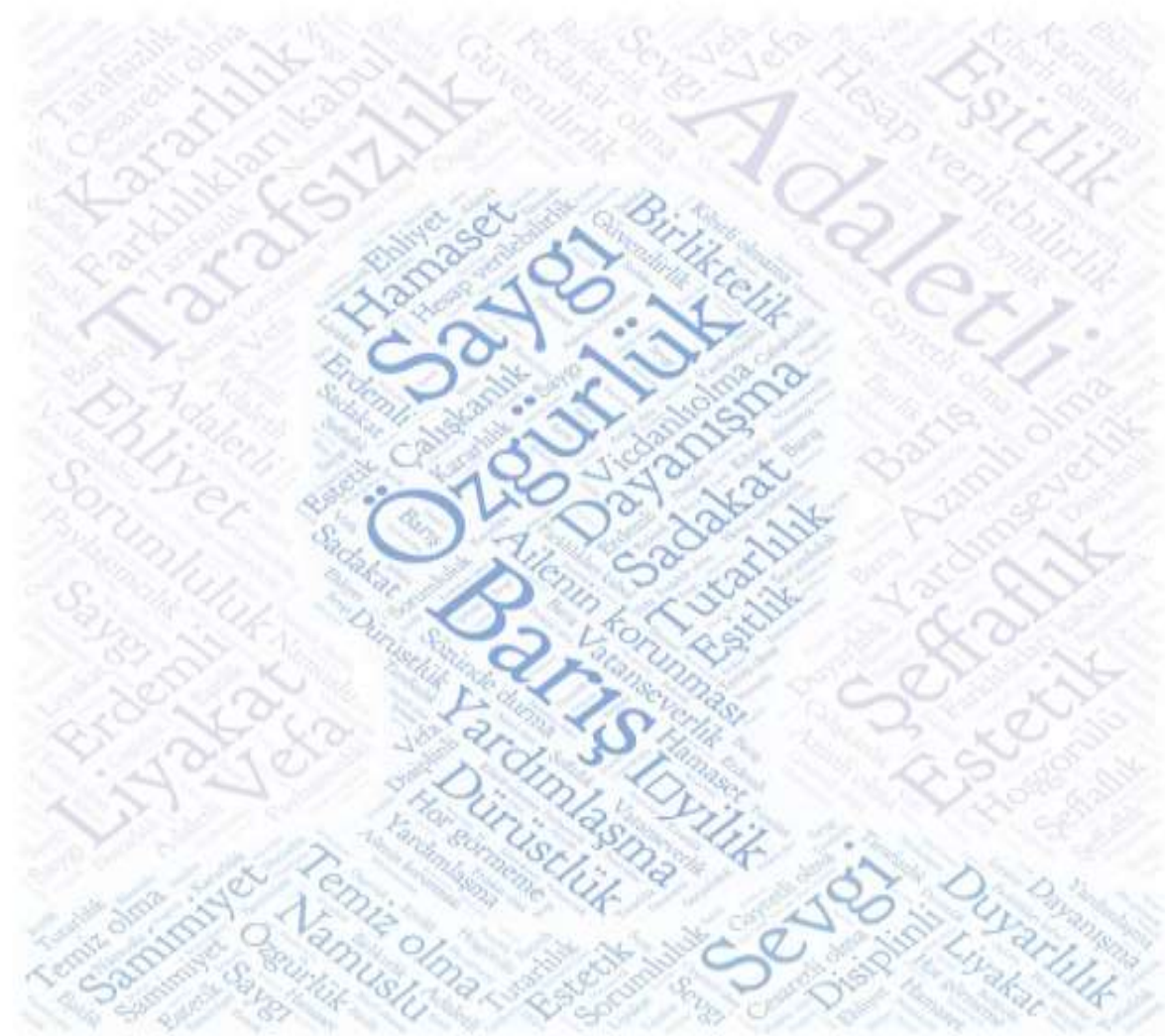

Şekil 3. Siyasi partilerin seçim beyannamelerinde geçen değerler

Araştırma kapsaminda değerler muhafazakâr-geleneksel, ulusal, bireye özgü-kişisel, sosyal-toplumsal ve bilimsel-yenilikçi değerler olarak isimlendirilmiştir. Aşağıda bu boyutlara göre bulgular tablolarda sunulmuştur. 
Tablo 3.Siyasi partilerin seçim beyannamelerinde yer alan muhafazakâr-geleneksel değerler

\begin{tabular}{|c|c|c|c|c|c|}
\hline MUHAFAZAKÂR-GELENEKSEL DEĞERLER & AK PARTI & MHP & $\mathrm{CHP}$ & İYí & HDP \\
\hline Ailenin korunması / aile birliği & 4 & 7 & 2 & 2 & - \\
\hline Sevgi & - & 7 & - & 1 & - \\
\hline Sevgi & & 5 & & 1 & \\
\hline Vatan sevgisi & & 1 & & & \\
\hline Millet sevgisi & & 1 & & & \\
\hline Fedakâr olma & - & 3 & 1 & - & - \\
\hline Fedakâr & & 1 & 1 & & \\
\hline Bencil olmama & & 1 & & & \\
\hline Feragatli olma & & 1 & & & \\
\hline Vefa & & 1 & & 2 & \\
\hline Ahde vefa & & & & 2 & \\
\hline Şühedaya vefa & & 1 & & & \\
\hline Vicdanlı olma & - & & - & 1 & - \\
\hline Namuslu olma & - & 1 & - & - & - \\
\hline
\end{tabular}

Tablo 4 incelendiğinde ailenin korunması, sevgi, fedakâr olma, vefa, vicdanlı ve namuslu olma değerleri ön plana çıkmıştır. "Ailenin korunması" değeri en çok MHP beyannamesinde ifade edilirken, ikinci en çok vurgu AK Parti tarafından, en az vurgu CHP ve İYİ Parti tarafından yapılmış olup, HDP de ise hiç vurgulanmamıştır.

- "Sevgi" değeri bakımından en çok vurgu MHP tarafından ve en az vurgu İYİ Parti tarafından yapılmış olup, diğer hiçbir parti vurgu yapmamıştır.

- "Fedakâr olma" değerine bakıldığında en çok vurgu MHP tarafından, en az vurgu ise CHP tarafından yapılmış olup, diğer hiç bir parti vurgu yapmamıştır. MHP partisi seçim beyannamesinde fedakâr olma değeri "bencil olmama, feragatli olma" alt değerleri olarak vurgulanmıştır.

- "Namuslu olma”ya sadece MHP vurgu yapmıştır, diğerleri hiç vurgu yapmamiştır.

Tablo 4. Siyasi partilerin seçim beyannamelerinde yer alan ulusal değerler

\begin{tabular}{|c|c|c|c|c|c|}
\hline ULUSAL DEĞERLER & AK PARTI & MHP & CHP & İYi & HDP \\
\hline Sadakat & & 8 & & & \\
\hline Vatana sadakat & & 3 & & & \\
\hline Millete sadakat & & 1 & & & \\
\hline Ezana sadakat & & 1 & & & \\
\hline Bayrağa sadakat & & 1 & & & \\
\hline Mukaddesata sadakat & & 1 & & & \\
\hline Devlete sadakat & & 1 & & & \\
\hline Vatanseverlik & & 1 & & & \\
\hline
\end{tabular}


Ulusal değerlere bakıldığında "sadakat" ve "vatanseverlik" değerleri ön plana çıkmış olup bunlara tek vurgu MHP tarafından yapılmıştır. "Sadakat" değeri alt boyutunda ise "vatana sadakat"in beyannamede ön plana çıktığ1 ifade edilebilir. Diğer hiçbir parti bu değerlere vurgu yapmamıştır.

Araştırma kapsamında seçim beyannamesinde yer alan değerler bireye özgü değerler açısından da analiz edilmiştir. Elde edilen bulgular Tablo $6^{\prime}$ da sunulmuştur.

Tablo 6. Siyasi partilerin seçim beyannamelerinde yer alan bireye özgü kişisel değerler

\begin{tabular}{|c|c|c|c|c|c|}
\hline BİREYE ÖZGÜ DEĞERLER & AK PARTI & MHP & $\mathrm{CHP}$ & İYí & HDP \\
\hline Sorumluluk & 24 & 20 & 7 & 12 & 1 \\
\hline Dürüstlük & 12 & 22 & 9 & 13 & 2 \\
\hline Dürüstlük & & 5 & 2 & 1 & \\
\hline Yolsuzluk-usulsüzlük yapmama & 12 & 17 & 7 & 12 & 2 \\
\hline Hesap verilebilirlik & 18 & 5 & 8 & 18 & 1 \\
\hline Tarafsızlık & 19 & 4 & 13 & 10 & 2 \\
\hline Liyakat & 5 & 2 & 17 & 7 & 2 \\
\hline Kararlılık & 16 & 3 & 5 & 3 & \\
\hline Farklılıkları kabul & 7 & 4 & 1 & & 7 \\
\hline Gayretli olma & 10 & 5 & & 3 & \\
\hline Temiz olma & 8 & 2 & 2 & 1 & 4 \\
\hline Paylaşımcılık & 4 & 3 & 6 & 1 & 2 \\
\hline Estetik & 8 & 1 & 2 & & \\
\hline Ehliyet & 2 & & 5 & 3 & \\
\hline Samimiyet & 2 & 2 & 3 & 2 & \\
\hline Cesaretli olma /hamaset & 2 & 2 & 4 & & \\
\hline Azimli olma & & 7 & & & \\
\hline Erdemli & 1 & 5 & & & 1 \\
\hline Tutarlılık & 1 & 2 & 2 & 1 & \\
\hline Hor görmeme & & 1 & & & \\
\hline Disiplinli & & 1 & & & \\
\hline Güvenilirlik & & & 1 & & \\
\hline Çalışkanlık & & & 1 & & \\
\hline Kibirli olmama & & & 1 & & \\
\hline İyilik & & & & 1 & \\
\hline
\end{tabular}

Bireye özgü değerlere bakıldığında sorumluluk değerinin en çok; disiplin, güvenilir olma, çalışkanlık, kibirli olmama ve iyilik değerlerinin ise en az vurgulanan değerler olduğu görülmektedir.

"Sorumluluk" değerine en çok vurgu AK Parti tarafından, ikinci en çok vurgu MHP tarafindan ve en az vurgu ise HDP tarafından yapılmıştır. Beyannamelerde ifade edilen ikinci en fazla değer “Dürüstlük" tür. Bu değere 
en çok vurgu MHP tarafından, ikinci en çok vurgu IYẎ Parti tarafından, en az vurgu ise HDP tarafından yapılmıştır.

Tablo 7. Siyasi partilerin seçim beyannamelerinde yer alan sosyal toplumsal değerler

\begin{tabular}{|c|c|c|c|c|c|}
\hline SOSYAL-TOPLUMSAL DEĞERLER & AK PARTI & $\underline{\mathrm{MHP}}$ & $\underline{\mathrm{CHP}}$ & $\underline{\dot{I} Y \dot{I}}$ & $\underline{\mathrm{HDP}}$ \\
\hline Özgürlük & 53 & 27 & 32 & 36 & 41 \\
\hline Özgürlük & 43 & 12 & 5 & 18 & 17 \\
\hline Sendika & 1 & 2 & 10 & 2 & 4 \\
\hline Vicdan özgürlüğü & & 6 & & 2 & 3 \\
\hline İfade özgürlüğü & 1 & & 2 & 2 & 4 \\
\hline Örgütlenme & & & 3 & & 5 \\
\hline Basin & 1 & & 1 & 2 & 3 \\
\hline İnanç özgürlüğü & 1 & & & 4 & 2 \\
\hline Teşebbüs özgürlüğü & 2 & 2 & & 1 & \\
\hline Toplantı /gösteri & 1 & 1 & 2 & 1 & \\
\hline Sosyal medya & & & 2 & & 2 \\
\hline Dini inanç özgürlüğü & & 2 & & & 1 \\
\hline Eleştiri & 1 & & 2 & & \\
\hline Medya özgürlüğü & & & 1 & 2 & \\
\hline Haberleşme & & 1 & & 1 & 1 \\
\hline İbadet & & & 2 & & \\
\hline Akademik & & & 1 & 1 & \\
\hline Cinsiyet & 1 & & & & 1 \\
\hline Fikir/düşünce özgürlüğü & & & & & 1 \\
\hline Kanaat özgürlüğü & & 1 & & & \\
\hline Eğitim özgürlüğü & 1 & & & & \\
\hline Seyahat & & & 1 & & \\
\hline Adaletli olma & 56 & 47 & 35 & 9 & 17 \\
\hline Adalet & 39 & 33 & 11 & & 13 \\
\hline Hakkaniyet & 10 & 9 & 9 & 3 & \\
\hline Sosyal adalet & 1 & & 5 & 6 & 1 \\
\hline Gelir dağılımı & 1 & 2 & 5 & & 1 \\
\hline Vergi adaleti & & & 5 & & \\
\hline Temsil & & 2 & & & 2 \\
\hline Katsayı (İmam hatip) üniversite sınavı & 2 & & & & \\
\hline Yarg1 & & 1 & & & \\
\hline Küresel adalet & 1 & & & & \\
\hline Çocuk adaleti & 1 & & & & \\
\hline Eğitim & 1 & & & & \\
\hline Barış & 32 & 33 & 21 & 14 & 20 \\
\hline Toplumsal & 4 & 12 & 12 & 5 & 16 \\
\hline Dünya & 11 & 13 & 2 & 6 & 1 \\
\hline Bölge & 11 & 7 & 6 & 3 & 3 \\
\hline Çalışma & 3 & 1 & 1 & & \\
\hline İmar & 3 & & & & \\
\hline
\end{tabular}


Araştırmada seçim beyannamelerinde yer alan değerler sosyal-toplumsal değerler olarak da analiz edilmiştir. Elde edilen sonuçlar ise Tablo 7'de verilmiştir.

Partilerin seçim beyannameleri sosyal-toplumsal değerler açısından incelendiğinde özgürlük, adaletli olma ve barış değerlerinin ön plana çıtığ 1 görülmektedir.

Özgürlük değeri en çok AK Parti tarafından vurgulanırken, en az ise MHP seçim beyannamesinde ifade edildiği görülmüsstür. Partiler özgürlük değeri kapsamında en çok genel özgürlük ve sendikal özgürlüğe vurgu yaparken en az ise kanaat, eğitim ve seyahat özgürlügüne vurgu yaptıkları görülmektedir.

Adalet değeri ise en çok AK Parti seçim beyannamesinde geçerken en az İYI Partide geçmektedir. Bu değer kapsamında ise en çok hakkaniyet değerine vurgu yapılırken en az küresel, çocuk ve eğitim adaleti değerlerine vurgu yapılmaktadır.

Tablo 7'nin devamı. Siyasi partilerin seçim beyannamelerinde yer alan sosyal toplumsal değerler

\begin{tabular}{|c|c|c|c|c|c|}
\hline SOSYAL-TOPLUMSAL DEĞERLER & AK PARTI & MHP & $\underline{\mathrm{CHP}}$ & $\underline{\underline{i} Y \dot{I}}$ & $\underline{\text { HDP }}$ \\
\hline Eşitlik & 14 & 11 & 16 & 8 & 13 \\
\hline Fırsat ve imkân & 8 & 3 & 3 & 5 & 1 \\
\hline Eşitlik & 4 & 4 & 6 & 3 & 3 \\
\hline Cinsiyet & 1 & 2 & 5 & & 5 \\
\hline Sosyal & & & & & 3 \\
\hline Siyasal & & 1 & 1 & & \\
\hline Yurttaşlık & & & 1 & & 1 \\
\hline Sağlık & & 1 & & & \\
\hline Eğitim & 1 & & & & \\
\hline Sayg1 & 12 & 13 & 8 & 6 & 4 \\
\hline Saygi & 2 & 6 & & 4 & \\
\hline İnsan haklarına sayg 1 & 2 & & 3 & 1 & 1 \\
\hline Farklı yaşam tarzı & 4 & & & & \\
\hline Doğaya çevreye & & & 2 & 1 & \\
\hline Toprak bütünlügüüne & 2 & & 1 & & \\
\hline İnançlara sayg1 & & 2 & 1 & & \\
\hline Hukuka saygi & 2 & & 1 & & \\
\hline Kadına saygı & & 1 & & & 1 \\
\hline Millete sayg1 & & 1 & & & \\
\hline Hasta haklarına saygı & & 1 & & & \\
\hline Tarihe saygı & & 1 & & & \\
\hline Aile hayatına saygı & & 1 & & & \\
\hline Emeğe & & & & & 1 \\
\hline Cinsiyet kimliğine & & & & & 1 \\
\hline
\end{tabular}




\begin{tabular}{llllll} 
Dayanışma / yardımlaşma / yardımseverlik & $\mathbf{5}$ & $\mathbf{1 5}$ & $\mathbf{1 0}$ & $\mathbf{2}$ & $\mathbf{7}$ \\
\hline Duyarlılık & $\mathbf{1 3}$ & $\mathbf{8}$ & $\mathbf{5}$ & $\mathbf{5}$ & $\mathbf{5}$ \\
\hline İsraf etmeme /tasarruf & 4 & 2 & 4 & 2 & 4 \\
$\begin{array}{l}\text { Yetim hakkı koruma } \\
\text { Toplumsal }\end{array}$ & 6 & 2 & & & 1 \\
$\begin{array}{l}\text { Çevreyi koruma /doğayı koruma } \\
\text { Milli }\end{array}$ & 1 & 3 & & 2 & \\
\hline Şeffaflık & 2 & & 1 & 1 & \\
\hline Birliktelik & $\mathbf{1 6}$ & $\mathbf{1}$ & $\mathbf{2}$ & $\mathbf{1 1}$ & \\
\hline Kardeşlik & $\mathbf{6}$ & $\mathbf{1 3}$ & $\mathbf{6}$ & & $\mathbf{1}$ \\
Halkların kardeşliği & 6 & 13 & 6 & & \\
\hline Hoşgörülü olma & & & & & 1 \\
\hline
\end{tabular}

Sosyal toplumsal değerlere vurgu bakımından seçim beyannameleri incelendiğinde, partilerin en az vurguladığı değerler şeffaflık, birliktelik ve hoşgörülü olma değerleridir.

Şeffaflık değeri en fazla AK Parti seçim beyannamesinde ifade olarak geçerken, en az MHP'de geçmektedir. HDP seçim beyannamesinde ise bu değere vurgu yapılmamıştır. Birliktelik değeri ise en çok MHP tarafından ifade edilirken, en az HDP tarafından vurgulanmıştır. İYI Parti tarafından ise vurgulanmadığı görülmektedir. Hoşgörülü olma değerinin ise sadece MHP seçim beyannamesinde vurgulandığı görülmektedir.

Araştırma sürecinde siyasi partilerin seçim beyannamelerindeki metinlerde yer alan değerler genel olarak değerlendirildiğinde, değerler muhafazakâr-geleneksel, ulusal, bireye özgü ve sosyal toplumsal değerler olarak analiz edilmiştir. Bu değerler arasında bireye özgü ve sosyal değerlere daha çok yer verildiği görülmektedir.

Muhafazakâr değerler arasında yer alan, fedakarlık, sevgi, vicdanlı olma, ailenin korunması, namuslu olma ve vefa değerleri beyannamelerde az yer verilen değerlerdir. Muhafazakar değerine beyannameye göre en çok MHP'nin önem verdiği anlaşılmaktadır. HDP ise bu değerlere hiç yer vermemiştir. Ulusal değerler boyutunda da vatana, millete sadakat gibi değerlere yine sadece MHP beyannamesinde yer verildiği görülmektedir.

Çalışmada dikkat çeken sonuçlardan biri bireye özgü değerlerde görülmektedir. Ülkemizde en çok tartışlan konulardan biri olan "liyakat, ehliyet" değerleri muhalif partiler olan CHP, İYİ Parti ve HDP tarafindan belirtilmektedir.

Adalet kavramı başta iktidar partisi olmak üzere diğer partilerde de çok sık kullanılan bir değerdir. Adaletli olma en çok iktidarda olan AK Parti 
tarafından dile getirilmiştir. Fakat partilerin "adalet" değerine yükledikleri anlamların farklılaştı̆̆ı görülmüştür. İktidar partisinin, imam hatiplilere katsayıda, eğitimde adalet ve hakkaniyet dışında çok detaya girmediği görülmektedir. MHP ise hakkaniyete, gelir dağılımında, temsilde, yargıda adaletli olmaya vurgu yapmıştır. Gelir dağılımında adalet ise en çok CHP tarafından belirtilmiştir.

Araştırmada dikkat çeken bir diğer bulgu ise "özgürlük" değeri ile ilgilidir. Özgürlük tüm siyasi partiler tarafindan yüksek oranda vurgulanmış olmasına ragmen, alt boyutlar incelendiğinde özgürlük anlayışının farklılaştığı ve yaklaşık 23 tür özgürlük anlayışının ortaya çıtığı görülmektedir. Aynı durum "eşitlik, barış, saygi" gibi değerlerde de olduğu görülmektedir.

\section{Araştırmanın Dördüncü Sorusu Ile Ilgili Bulgular}

Siyasi partilerin seçim beyannamelerinde yer alan değerlerin kaynaklarının ne olduğu sorusu araştırılmıştır. Bu konuda da siyasi partiler arasında farklılıklar olduğu görülmektedir. Elde edilen bulgular Tablo 8'de verilmiştir.

Tablo 8. Siyasi partilerin seçim beyannamelerinde yer alan değer kaynaklarn

\begin{tabular}{|c|c|c|c|c|c|}
\hline DEĞER KAYNAKLARI & AK PARTI & MHP & $\mathrm{CHP}$ & İYI & HDP \\
\hline İnsana dair değerler & 1 & & & 1 & 17 \\
\hline Demokratik değerler & & & & 1 & 13 \\
\hline Evrensel değerler & 4 & & 1 & & 1 \\
\hline Cumhuriyet değerleri & & & 1 & & 4 \\
\hline Laiklik & & 1 & 3 & & 1 \\
\hline Milli değerler & 3 & 1 & & 1 & \\
\hline Türkiye halkları & & & & & 4 \\
\hline Ahlaki değerler /moral değerler & 1 & & & 1 & \\
\hline Manevi değerler & & 1 & & 1 & \\
\hline Ortak değerler & 1 & & & & 1 \\
\hline Örf ve adetler & & & & 1 & 1 \\
\hline Anadolu irfanı & & 1 & & & \\
\hline Atatürk İlkeleri & & & 1 & & \\
\hline Atatürk milliyetçiliği & & & 1 & & \\
\hline Çağdaş değerler & & & 1 & & \\
\hline Dini değerler & 1 & & & & \\
\hline Folklorik & 1 & & & & \\
\hline İslam & & 1 & & & \\
\hline Sosyal demokratik değerler & & & 1 & & \\
\hline Türk milliyetçiliği & & 1 & & & \\
\hline Türk-İslam kültürü & & 1 & & & \\
\hline Türklük & & 1 & & & \\
\hline
\end{tabular}


Siyasi partilerin seçim beyannamelerinde yer alan değerlerin kaynakları incelendiğinde en çok vurgulanan değer kaynakları insana dair değerler ile demokratik değerlerdir. En az vurgulananlar ise Türk milliyetçiliği, Türkİslam kültürü ve Türklüktür.

İnsana dair değer kaynakları en fazla HDP seçim beyannamesinde geçmektedir. En az ise AK Parti ve İyi Parti beyannamelerinde geçerken MHP ve CHP'nin bu değer kaynağına vurgu yapmadığı görülmektedir. Demokratik değerlere ise sadece HDP ve İYİ Parti seçim beyannamelerinde yer verilmiştir. Diğer partilerin ise yer vermediği görülmektedir.

En az vurgu yapılan değerler incelendiğinde ise (Türk milliyetçiliği, Türkİslam kültürü ve Türklüktür) bu değerlere sadece MHP seçim beyannamesinde vurgu yapıldığı ortaya çıkmıştır.

AK Parti'nin evrensel değerlere çok önem verdiği görülmektedir. Milli Eğitim Banaklığı 2023 vizyon belgesinde de "milli" kavramı 4 kez geçerken "evrensel” 17 kez geçmektedir. MHP “Anadolu irfanı, İslam, laiklik, manevi değerler, milli değerler, Türk Milliyetçiliği, Türk-İslam Kültürü ve Türklük" gibi daha çeşitli değer kaynakları ile daha birleştirici mesaj verdiği söylenebilir. CHP'de "Atatürk ilkeleri, Cumhuriyet değerleri, Çağdaş değerler, laiklik" gibi değer kaynakları parti politika ve söylemleri ile tutarlı görülmektedir. HDP ise "demokratik değerler ve insana ait değerlere" vurgu yapmaktadir.

\section{Araştırmanın Beşinci Sorusu Ile Ilgili Bulgular}

Araştırma kapsamında siyasi partilerin seçim beyannamelerinde yer alan “tutum"ların neler olduğu analiz edilmiştir. 
Tablo 9. Siyasi partilerin seçim beyannamelerinde yer alan tutumlar

\begin{tabular}{|c|c|c|c|c|c|}
\hline TUTUM & AK PARTI & MHP & CHP & İYí & HDP \\
\hline Haklar & 6 & 6 & 1 & 3 & 22 \\
\hline Engelli haklarını savunma & & 1 & & & 15 \\
\hline Hukukun üstünlüğü isteme/talep etme & 4 & 1 & 1 & & 1 \\
\hline İnsan hakları üstünlüğü isteme/talep etme & & 1 & & 1 & 4 \\
\hline Kadın hakları savunma & & & & 1 & 1 \\
\hline Temel hak ve özgürlükler garanti altına alma+ & 1 & & & & \\
\hline İşkence ve eziyete karşı olma & & 1 & & & 1 \\
\hline Bireysel hak ve özgürlüklerin koruma & & & & 1 & \\
\hline $\begin{array}{l}\text { Her insanin dokunulmaz, devredilmez ve vazgeçil- } \\
\text { mez temel hak ve özgürlükleri bulunduğuna } \\
\text { inanma }\end{array}$ & & 1 & & & \\
\hline Vatandaşın hak ve hürriyetlerini koruma & 1 & & & & \\
\hline Yaşama hakkını savunma & & 1 & & & \\
\hline Politik tutumlar & 12 & 5 & 2 & 2 & 7 \\
\hline Demokrasinin güçlenmesini isteme & 6 & 1 & & & \\
\hline Yerel Demokrasi & & & & & 5 \\
\hline Çoğulculuk & 2 & & 1 & & \\
\hline İnsanı yaşat devlet yasasın anlayışı & 2 & & & & \\
\hline İnsanı merkeze alma & 1 & & & & 1 \\
\hline Milli irade & 1 & & & 1 & \\
\hline $\begin{array}{l}\text { "Tek vatan, tek bayrak, tek millet, tek devlet, tek dil" } \\
\text { anlayışını hâkim kılma ve yaşatma iradesi }\end{array}$ & & 1 & & & \\
\hline $\begin{array}{l}\text { Atatürk ilkeleri ve Cumhuriyet değerleri ışığında } \\
\text { çağdaş, demokratik, laik, bilimsel ve eşitlik ilkesine } \\
\text { dayalı bir anlayıs }\end{array}$ & & & 1 & & \\
\hline Laik ve barışçı bir politikayı egemen kılma & & & & & 1 \\
\hline Demokratik toplumu isteme & & & & 1 & \\
\hline Yaşa ve yaşat ilkesi & & 1 & & & \\
\hline Önce milleti anlayıșı & & 1 & & & \\
\hline Önce ülkem anlayışı & & 1 & & & \\
\hline
\end{tabular}

Siyasi partilerin seçim beyannamelerinde yer alan tutumlar incelendiğinde en çok vurgulanan tutumların "haklar" ve "politik tutumlar" olduğu ortaya çıkmıştır.

"Haklar" tutumuna en çok değinen HDP olurken en az değinen parti ise CHP'dir. "Haklar" konusunda en çok değinilen noktalar engelli haklarını savunma, hukukun ve insan haklarının üstünlügüünün istenmesidir.

"Politik tutumlar" konusuna en çok değinen parti AK Parti olurken en az CHP ve IYYI Partinin değindiği görülmektedir. "Politik tutumlar" için de ise "demokrasinin güçlenmesini isteme" ve "yerel demokrasi"nin ön plana çıktığı ifade edilebilir. 
Tablo 9'un devamı. Siyasi partilerin seçim beyannamelerinde yer alan tutumlar

\begin{tabular}{|c|c|c|c|c|c|}
\hline TUTUM & AK PARTİ & MHP & CHP & İYİ & HDP \\
\hline Değerler & 2 & 7 & 3 & 3 & 12 \\
\hline Evrensel değerler içselleştirme & 1 & & & & \\
\hline Aşağılayıcı davranış ve uygulamalara karşı olma & & 1 & & & \\
\hline Bir arada yaşama arzusu & & & 1 & & 3 \\
\hline Dini kullanmama & & & & 1 & 1 \\
\hline Farkl1 yaşam tarzlarına ve inançlara sayg1 & & & 1 & & 2 \\
\hline Farklılıkları zenginlik olarak görme & & & & 1 & 3 \\
\hline Manevi ve kültürel değerleri özümseme & & 1 & & & \\
\hline Milli değerleri evrensel değerlerle buluşturma & 1 & & & & \\
\hline \multicolumn{6}{|l|}{ Evrensel hukuk ve yargılama ilkelerini kabul etme } \\
\hline İslam ahlak ve faziletine sahip olma & & 1 & & & \\
\hline Milli ve manevi değerleri çatışma konusu yapmama & & 1 & & 1 & \\
\hline Milli ve manevi değerleri güçlendirme & & 1 & & & \\
\hline $\begin{array}{l}\text { Türk milletine mensubiyetin gurur ve şuuruna sahip } \\
\text { olma değerlerini tanıma }\end{array}$ & & 1 & & & \\
\hline Otoriteye boyun eğmeme & & & & & 3 \\
\hline Türklük gurur ve şuuruna sahip olma & & 1 & & & \\
\hline Sosyal adaleti temel kabul etme & & & 1 & & \\
\hline Devlet ile ilgili & 1 & 5 & 1 & 1 & \\
\hline Devletin kudretini arzu etme & & 1 & & & \\
\hline Devletin ve milletin bekasını düşünme & & 1 & & & \\
\hline Devletçilik & & & 1 & & \\
\hline Sorumlu devlet anlayışı & & & & 1 & \\
\hline Türkiye'nin huzurlu geleceğini arzu etme & & 1 & & & \\
\hline Türkiye'nin onurlu geleceğini arzu etme & & 1 & & & \\
\hline Müreffeh Türkiye arzusuna sahip olma & 1 & 1 & & & \\
\hline Milli birlik ve beraberlik & 1 & 1 & 1 & & \\
\hline Milletin temel değerleri dayalı birliktelik & 1 & & & & \\
\hline Millî birlik ve bütünlüğü zedelememe & & 1 & & & \\
\hline Yurtta Barış, Dünyada Barış" & & & 1 & & \\
\hline
\end{tabular}

Seçim beyannamelerinde yer alan tutumlar incelendiğinde en az vurgulanan tutumların devletle ilgili ve milli birlik -beraberlik konusunda tutumlar olduğu ortaya çıkmıştır.

"Devlet ile ilgili" tutum boyutu incelendiğinde en çok vurgunun MHP tarafından yapıldığı ortaya çıkmıştır. HDP'nin ise hiç vurgu yapmadığı görülmüştür. Milli birlik ve beraberlik boyutunda ise sadece üç partinin -AK Parti, MHP ve CHP- birer kez vurgu yaptığı ortaya çıkmıştır.

Araştırma kapsamında son olarak siyasi partilerin seçim beyannamelerinde yer alan tutumlar incelenmiştir. Tutumların "devlet, haklar, politik, 
milli birlik-beraberlik ve değerler" temalarında yer aldığı belirlenmiştir. Siyasi partiler arasında MHP'nin daha çok tutuma yer verdiği görülmektedir.

\section{Sonuç ve Öneriler}

Bu çalışmada, TBMM'de grubu bulunan beş siyasi partinin 24 Haziran 2018 tarihinde yapılan Cumhurbaşkanlığı ve Milletvekili Genel Seçimi öncesinde seçim bildirgelerinde yer alan görüşlerden hareketle hedefledikleri insan karakterini karşılaştırmalı olarak analiz edilmesi amaçlanmıştır. Bu bağlamda siyasi partilerin seçim beyannameleri "değerler, beceriler, değer kaynakları ve tutum" boyutları açısından analiz edilmiştir.

Araştırma bulgularından elde edilen sonuçlar aşağıdaki gibidir:

- Siyasi partiler içerisinde seçim beyannamesinde en fazla kelime içeriği AK Partide, en az ise HDP de yer almaktadır.

- Ortak kültürel unsurlara ait "Türk, Atatürk, Vatan, Türk Milleti, İslam" gibi kavramların siyasi partilerin seçim beyannamelerinde farklı düzeylerde yer aldığı, partilerin bu konuda farklı görüşlere sahip olduğu belirlenmiştir.

- 21.yy becerilerine siyasi partilerin yeterince yer vermediği belirlenmiştir. İnisiyatif alma ile sosyal ve vatandaşlık becerisi siyasi parti seçim beyannamelerinde en çok yer alan becerilerdir. İletişim, bilgi, medya ve teknoloji becerileri, finansal okuryazarlık, özgüven, değişime açı olma daha az yer verilen becerilerdir. 21 yy. becerileri niceliksel olarak en çok AK Parti en az HDP beyannamesinde yer almaktadır.

- Araştırma kapsamında seçim beyannamesinde yer alan değerler muhafazakâr-geleneksel, ulusal, bireye özgü-kişisel, sosyal-toplumsal ve bilimsel-yenilikçi değerler olarak sınıflandırılmıştır. Bireye özgü ve sosyal-toplumsal değerler az fazla yer alan değerlerdir. Değerlere en çok vurgu AK Parti en az HDP tarafından yapılmıştır. Değerler boyutunda partiler arasında farklılıklar görülmektedir.

- Partilerin seçim beyannamelerinde değer kaynakları boyutunda da farklı görüşler olduğu belirlenmiştir. HDP demokratik değerler ve insana dair değerlere daha çok vurgu yapmaktadır. Değer kaynaklarında çeşitlilik ise en çok MHP seçim beyannamesinde yer almaktadır. 
MHP'nin daha çok birleştirici değer kaynaklarını beyan ettiği görülmektedir.

- Partilerin seçim beyannamelerinde yer alan tutumların devlet, haklar, politik, milli birlik ve değerler başlıkları altında toplandığı görülmektedir. Tutum boyutunda partilerin farklı görüşlere sahip oldukları görülmektedir.

- Sonuç olarak siyasi partilerin seçim beyannameleri, 21 yy. becerileri, değerler, tutumlar ve değerlerin kaynakları bağlamında bütüncül olarak değerlendirildiğinde yetiştirilmek istenen insan tipinin net olmadığı görülmektedir. Ayrıca HDP’nin seçim beyannamesinin odak noktalarının diğer partilerden farklılaştığı görülmektedir. HDP beyannamesinde yer alan metinler yetiştirilmek istenen insan tipine yönelik verileri tam olarak sunmamaktadır.

Araştırma kapsamında elde edilen sonuçlardan hareketle aşağıdaki öneriler getirilebilir:

Araştırmacılara yönelik öneriler

- Bu tür çalışmalar sadece partilerin seçim beyannameleri değil parti programları ve söylemleri ile genişletilerek yapılabilir.

- Siyasi partilerin seçim beyannameleri üzerinde boylamsal çalışmalar yapılabilir. Bu şekilde partilerin politika ve söylemlerindeki değişim ve gelişmeler de ortaya çıarılabilir.

- Bu tür çalışmalarda veri çeşitlemesi yapılabilir. Örneğin parti temsilcilerinin görüşlerine de başvurulabilir.

Politika geliştiricilere yönelik öneriler

- Siyasi partiler hedefledikleri insan tipini net biçimde açıklayabilirler.

- Siyasi partilerin herkesi kucaklayıc kültürel unsurlara odaklanmasi önerilebilir. 


\title{
EXTENDED ABSTRACT
}

\section{Analysis Of Human Characters Aimed By Political Parties In Their Election Campaign Manifestos}

\author{
Erdal Bay - Recep Kahramanoğlu - Bülent Döş - Ümit Polat \\ Gaziantep University, Ömer Halisdemir University
}

Political parties share what they want to do through election declarations. The election declarations are the texts of the statements that the political parties establishing the link between the society and the state, when they come to power, publicly disclose their policies. Election promises, party programs as well as election statements explain the views of political parties. In election declarations, it can be seen in the characteristics that the political parties want to train besides economic and social areas.

When the literature is analyzed, it is seen that some studies that do not have any direct studies on the human profile targeted by the parties are related to the educational discourses and policies of political parties (Gürsoy \& Balcı Karaboğa, 2015; Toprakçı \& Akçay Güngör, 2014; Tok, 2012; Bulut \& Güven, 2010; Aydın , 1997). Turkish Education Association (TEDMEM) (2018) has published a report titled "Comparison of policies and promises in the field of education of the 2018 election declarations of political parties". In this report, election declarations of political parties were analyzed under 23 themes related to the field of education. In the related study, the human profile of political parties were not examined as a theme.

In this study, what type of people we want to train in the declarations of the political parties in the light of 2023 vision document. Election declarations of five (5) political parties which have groups in the Turkish Grand National Assembly were analyzed.

\section{Research Questions}

The main purpose of the study is to analyze the human character targeted by the five political parties that have a group in the Turkish Grand National Assembly, based on the opinions in the election declarations prior to 
the Presidential and Deputy General Elections held on June 24, 2018. In this context, answers to the following questions were sought.

1. How many words are the political parties' election statements and which words / concepts are the most emphasized?

2. What are the 21st century skills included in the election declarations of political parties?

3. What are the values included in the election declarations of political parties?

4. What are the sources of the values included in the election declarations of political parties?

5. What attitudes are included in the election declarations of political parties?

\section{Method}

In this study, document analysis method was used by analyzing the literature. The documents were collected only from the five political parties which have groups in the parliamentary of all political parties operating in Turkey. Party declarations have been downloaded from the official websites of the parties. Election declarations were preferred primarily because they are the most official documents reflecting the policies of the parties. In this context, research is limited to election declarations only. Discourses other than the election declaration are not included in the study.

In the analysis of data, it was discussed whether all sections of election declarations or only sections on educational policies should be examined to determine the data for the human character that political parties target. All contents of the election declarations are included in the analysis, since they can be found in any size.

The fact that the research was made only with the election declarations and the parties in the assembly is limited. Another limitation is the absence of discourse analysis of findings and not being associated with political ideologies (eg neo-liberalism ...) that affect educational systems. 


\section{Results}

The emphasis on the concept of "Turkish" in the declarations was made mostly by the Nationalist Movement Party (NMP), and the least by the Peoples' Democratic Party (PDP). While the concept of "Atatürk" does not take place in the Justice and Development Party (JDP) and PDP, it is mostly in the Republican People's Party (RPP)and then in the NMP and the Good Party (GP). While the concept of "Homeland" is emphasized most in the NMP election declaration, RPP, GP and PDP have never been mentioned. Only NMP and RPP emphasized the concept of "Turkish Nation". It is most emphasized in the NMP statement. While the concept of "Islam" is expressed mostly by the JDP, it is emphasized in the NMP statement in the second place. RPP and PDP did not emphasize this concept. "Qur'an" is only included in the JDP election declaration as a concept.

The skills of "social and citizenship, communication, taking initiative, competence in mathematical and science technology, learning to learn", which are among 21st century skills, are included in the election declarations of all political parties. When looking at the skills in general, the most repeated skills are the ability to take initiative, social and citizenship skills and innovation skills. It is observed that features such as information literacy, ICT literacy, scientific process implementation, intercultural skills are not included in the election declarations of political parties.

The most emphasis on "social and citizenship skills" was made by the JDP, the second most emphasized by the RPP and the least emphasis by the PDP. The most emphasized skill in social and citizenship skills sub-dimension was "cooperation". It is seen that the skills such as "empathy, openness to communication, social skill, leadership", which are among the sub-dimensions of social and citizenship skills, are very few. "Cooperation", which is a sub-dimension of social and citizenship skills, was expressed mostly by the JDP, and least by the PDP. "Empathy" is specified only by NMP. It can be said that "Social and citizenship" skills, which are among 21st century skills, are not sufficiently included by political parties. It is seen that political parties do not sufficiently take part in their electoral declarations such as questioning, researcher, analytical, critical thinking, "learning to learn" skills, being open to change, and self-confidence. 
The values of family protection, love, self-sacrifice, loyalty, conscience and dignity have come to the fore. While the value of "protecting the family" is expressed mostly in the NMP declaration, the second most emphasized by the JDP, the least emphasis was made by the RPP and GP, and the PDP has not emphasized at all. When looking at the national values, the values of "loyalty" and "patriotism" came to the fore and the only emphasis was made by NMP. In the "loyalty" value sub-dimension, it can be stated that "loyalty to the homeland" came to the fore in the declaration. No other party has emphasized these values.

On the other hand, the value of "association" is emphasized by NMP, and least by PDP. It does not appear to be emphasized by the GP. It is seen that the value of tolerance is emphasized only in the NMP election declaration. It is understood that NMP attaches great importance to the conservative values according to the declaration. PDP has never included these values. In the national values dimension, it is seen that values such as loyalty to the homeland and the nation are included only in the NMP declaration. It is seen that the JDP attaches great importance to universal values. In the 2023 vision document of the Ministery of National Education, the concept of "national" is passed 4 times while "universal" is 17 times. It can be said that NMP gives a more unifying message with more diverse value sources such as "Anatolian wisdom, Islam, secularism, spiritual values, national values, Turkish Nationalism, Turkish-Islamic Culture and Turkishness". Value sources such as the RPP “Atatürk's principles, Republican values, Contemporary values, secularism" are considered consistent with party policies and discourses. PDP emphasizes "democratic values and human values".

Within the scope of the research, the attitudes included in the election declarations of political parties were also examined. It has been determined that attitudes are included in the themes of "state, rights, political, national unitysolidarity and values". Among the political parties, NMP appears to include more attitudes.

\section{Conclusion and suggestions}

- As a result, election declarations of political parties the type of people to be raised is not clear in the light of 21 century skills. In addition, it is seen that the focus points of PDP's election declaration differ from other 
parties. The texts in the PDP declaration do not fully provide the data for the type of person to be raised.

- Longitudinal studies can be conducted on the election declarations of political parties. In this way, changes and developments in the policies of the parties can be revealed.

\section{Kaynakça / References}

Akyüz, Y. (2007). Türk eğitim tarihi M.Ö. 1000 - M.S. 2012. (11. Baskı). Ankara:Pegem Yayıncilik.

Barlett, S. ve Burton, D. (2014). Eğitimde siyaset ve politika. (Çev. Ed. B. Aybek, Böl. çev: Ö.F. Vural), Ĕ̆itim Bilimine Giriş içinde, Ankara: Anı yayıncilık.

Bay, E. ve Döş, B. (2018). Sosyal, kültürel ve ahlaki bir kurum olarak okul. (E. Köse Ve S. Z. Genç Ed.). Eğitim Sosyolojisi içinde (s.190-208).

Binbaşıŏlu, C. (2005). Türk düşünce tarihi. Anı Yayıncılık: Ankara:

Bulut, P. ve Güven, S. (2010). Siyasi parti programlarında ilköğretim kademesinde gerçekleştirmeyi hedefledikleri düzenlemeler. Eğitimde Kuram ve Uygulama Dergisi. 6(2), 281-300.

Carr, W. (1998). The curriculum in and for a democratic society. Curriculum Studies, 6(3), 323-340. DOI:10.1080/14681369800200044.

CHP.(2018). Seçim bildirgesi. http://secim2018.chp.org.tr/files/CHP-

SecimBildirgesi-2018-icerik.pdf adresinden alınmıştır.

Çelebi, N. ve Asan, H. T. (2013). Cumhuriyet'in ilk yillarindaki (1923-1946) insan/birey yetiştirme paradigmasinin son osmanli birikimi ile karşilaştirmali analizi. Eğitim ve Öğretim Araştırmaları Dergisi, 2(1), 140-148.

Feinberg, W. (1983). Understanding education: Toward a reconstruction of educational inquiry. NewYork: Cambridge University Press.

Gürsoy, M. ve Balcı Karaboğa, A. (2015). Siyasi partilerin seçim bildirgelerinde eğitim konusu Route Educational and Social Science Journal, 2(4), 112-140.

HDP.(2018).Seçim Bildirgesi. https://drive.google.com/file/d/1E8L6KtBHbuctB4TxNM3YURSWdZ34Zj7/view adresinden alınmıştır.

Hesapçıŏlu, M. (2009). Türkiye'de cumhuriyet döneminde eğitim politikası ve felsefesi. M.Ü. Atatürk Eğitim Fakültesi Ĕ̆itim Bilimleri Dergisi, 29, 121-138.

Inglis, F. (1985). The Management of Ignorance: a political theory of the curriculum. Oxford: Basil Blackwell. 
İYİ.(2018).Seçim bildirgesi.

https://iyiparti.org.tr/assets/pdf/secim beyani.pdfhttps://iyiparti.org. tr// adresinden erişilmiştir.

Kelly, A. (2009). The curriculum: Theory and Practice, 6thedn London: Sage. Kelly

Köprülü, F.(2013).Türk edebiyatında ilk mutasavoıflar. Ankara: Akçağ Yayınevi.

Meşeci, F. (2007). Cumhuriyet sonrası Türk eğitim sisteminde ritüeller: Kuramsal bir çalı̧̧ma. Yayınlanmamış doktora tezi, İstanbul: Marmara Üniversitesi, Eğitim Bilimleri Enstitüsü.

MHP.(2018). Seçim bildirgesi

https:/www.mhp.org.tr/htmldocs/mhp/beyanname/mhp/mhp beya nnamesi.html 01.10.2018 tarihinde alınmıştır.

TEDMEM (2018). Siyasi partilerin 2018 seçim bildirgeleri Ĕ̆itim Alanındaki Politika ve vaatlerin Karşılaştırılması.

https://tedmem.org/download/siyasi-partilerin-2018-secimbildirgeleri-egitim-alanindaki-politika-vaatlerinkarsilastirilmasi?wpdmdl=2696 adresinden erişilmiştir.

Tok, T. N. (2012). Türkiye'deki siyasal partilerin eğitim söylemleri ve siyasaları. Kuram ve Uygulamada Eğitim Yönetimi [Educational Administration: Theory and Practice], 18(2), 273-312.

Toprakçı, E. ve Akçay Güngör, A. (2014) Türkiye'deki siyasal partilerin eğitim politikaları. Educational Policy Analysis and Strategic Research, 9(1), 5-35.

Yardımcı, M. (2007). Destanlar. Ankara: Ürün Yayınları.

Yıldırım, A. ve Şimşek, H. (2016) Sosyal bilimlerde nitel araştırma yöntemleri. Ankara: Seçkin Yayınları.

Yıldırmaz, S. (2018) 24 Haziran 2018 parti beyannameleri kelime analizi https://m.bianet.org/bianet/siyaset/198090-24-haziran-2018-partibeyannameleri-kelime-analizi adresinden erişilmiştir.

Young, M. (1999) Knowledge, learning and the curriculum of the future.British Educational Research Journal,25(4),463-477,DOI:10.1080/0141192990250404

\section{Kaynakça Bilgisi / Citation Information}

Bay, E., Kahramanoğlu, R., Döş, B. ve Polat, Ü. (2020) Siyasi partilerin seçim beyannamelerinde hedeflediği insan karakterlerinin analizi. OPUS-Uluslararası Toplum Araştırmaları Dergisi , 15(22), 1082-1113. DOI: 10.26466/opus.640943 